\title{
HIGHER EDUCATION OF SWEDEN: EUROPEAN STANDARDS AND SCANDINAVIAN STYLE
}

\author{
DMYTRO ZHELANOV
}

\begin{abstract}
The article analyzes certain aspects of the development of higher education in Sweden in the context of modern globalization and integration of socio-economic processes in the countries of the European Union. The article studies the position regarding the features of modern higher education, connected with its output beyond the limits of individual states and transformation into an international institution. It is proved that this circumstance determines significant achievements in the integrated development of the European higher education, leaving, at the same time, the risks of losing its national features and dropping the level of higher education in countries that are not well targeted for the welfare of the population. The necessity of taking into account the essence of these risks has been substantiated in order to increase the competitiveness of Ukrainian higher education institutions in their interrelation and cooperation with universities of Europe. The expediency of studying and introducing the best foreign experience in the national higher education system of the Scandinavian countries in particular and, namely, of Sweden, has been proved.
\end{abstract}

Keywords: Bologna Convention, globalization, European educational space, higher education in Sweden, universities, colleges, summer schools, countries of "welfare", "education throughout life", risks of Bologna reform.

\section{INTRODUCTION}

The fundamental changes in the socio-economic structure of our state place a fundamentally new task before the system of higher education in Ukraine. Education is becoming a strategic resource for improving people's well-being, ensuring national interests, strengthening Ukraine's credibility and competitiveness on the international arena. Such global functions of education need the improvement of its quality and the improvement of the education management system in order to create modern educational services of high quality, with maximum application of European experience. Taking into account the current European integration tendencies that are penetrating into all spheres of the modern society, it is expedient to analyze the essence and possibilities of using in the domestic educational space the achievements in the field of higher education of the leading countries of the world, and, in particular, of Sweden as one of the most developed Scandinavian countries.

The purpose of this article is to provide a critical analysis of the achievements and risks of implementing the Bologna reforms in Sweden. 


\section{ANALISIS AND DiscUSSION}

Different aspects of comprehension and borrowing of the positive ideas and achievements of higher education in Scandinavia, which contribute to the search and comprehension of the ways of reforming higher education in Ukraine, taking into account the world tendencies, are presented in the works of I. Burgun, N. Ivanyuk (general analysis of the education system of Sweden); L. Mozhayeva (modernization of the higher school of Sweden); N. Kosharna (education management in Sweden); T. Logvynenko (professional training of social pedagogues in Sweden); A. Ageycheva (peculiarities of distance education in Sweden); G. Vaskivska (humanistic principles of education in Norway); V. Vakhstein (higher education system in Norway); V. Stynska (Norwegian experience of forming a system of higher education in the context of the Bologna system); L. Volynets (artistic and cultural education in Norway); T. Grabovska (educational reforms in Norway); O. Matviyenko (educational system of modern Denmark). The strategies for the development of educational systems of the Scandinavian countries have been analyzed in the works by D. Kucherenko, O. Martynyuk. General questions of the functioning of the education systems of the Scandinavian countries were disclosed in the writings by M. Gromkova, V. Isayev, B. Yordan, L. Pesokhina, E. Sugrobova, L. Shkorkina. Higher education of the Scandinavian countries is the subject of scientific research by A. Kulikova, O. Ogiyenko, L. Filippovets, E. Kokkerservold, R. Lappen, T. Logvynenko, R. Lungstad, Ya. Peterson, R. Rasmussen, N.E. Svensson, V. Cyupaul, V. Tevlin, T. Hussen, T. Jensen, P. Sherkwist, S. Juliusdotyr, D. Jacobson.

The main areas of modernization of the European higher education were declared in the Bologna Declaration (June 19, 1999) and studied in the works by N. Abashkina, O. Vaulina, T. Desiatov, M. Dmytrychenko, O. Lokshyna, A. Sbruyeva, G. Khoruzhyi. Among the provisions of the abovementioned normative document, the following are more fundamental: for example, the inclusion in the national higher education systems of the European countries of a two-level (two-cycle) structure of the educational process with the levels of bachelor's and master's degrees; introduction of the accounting of the training load in the credit units (credits); the expansion of the opportunities for the implementation of the mobility of students and teachers of European universities in the format of international cooperation; strengthening of the single European dimension of the educational process, the creation of a holistic evaluation and quality assurance system for higher education in Europe; broad use of information and communication technologies in the educational process; improving the quality of teaching foreign languages. Thus, the leading tendencies and features of the Bologna system of education are its globalization, internationalization, humanitarization, humanization, democratization, continuity, mass character, technologisation. It is obvious that these positions are consonant with the main directions of modernization of the national higher education, declared in the Law of Ukraine "On Higher Education" (2014), which actualizes the expediency of studying, generalization and introduction of the experience of the European countries in the practice of modern higher education institutions.

It should be noted that in spite of the above-mentioned directions of the scientific discourse on the Scandinavian countries education and of Sweden, in particular, there is a certain narrowing of research topics, given that these "welfare states" position themselves outside the general course of "Europeanization" and have obvious national development peculiarities systems of university education, which sometimes contradict certain provisions of the Bologna Declaration. At the same time, modern systems of higher education in Scandinavia have reached a high level of development, ranking on many indicators of leading positions in the world rankings. Is this a paradox? Let us try to figure it out.

It is worth noting that the Swedes are learning almost all their lives. Continuing education is a part of the philosophy of the "lagom" (from the Swedish "lagom" - sufficient), according to which this Scandinavian country lives. It is the Swedish concept of life, the philosophy of harmony, which is based on the balance of only the most necessary things ("Moderation is the best of all", "Lagom är bäst") [3]. 
Let us consider the general "landscape" of the higher education system in Sweden. In our opinion, the research project "Education in 2000" (headed by Torsten Hüseen, a renowned Swedish professor, a leading theorist in the field of education and its reformation), highlighted the strategic guidelines for the modernization of the Swedish higher education, is of a considerable scientific interest.

As you know, the authors of the project have developed variants of forecasting models of education of Sweden at the end of XX - beginning XXI centuries and held discussions on this issue. Significant positions of this project were the following ones:

- democracy and economic development should ensure equality in the realization of the right of citizens for education;

- improving the education quality level;

- increase in the number of educational institutions;

- expansion of the list of professions and the emergence of new professional sectors coherent with rapid technical development;

- increase in the number of secondary and higher education students;

- compulsory schooling for young people under the age of 18;

- full technologicalization of school education;

- an increase in the number of students at universities ( $40 \%$ of the total number of young people aged from 20 to 25 years [12].

According to the estimation of a well-known researcher of the problem of education in the Scandinavian countries, T. Logvynenko, these and other forecasts expressed by scientists in the project have indeed gained a real incarnation in the European educational space, including Sweden and other Scandinavian countries, which demonstrate a high level of responsibility for the condition of higher education at different levels, namely: 1) legislative; 2) in financing; 3) in participation in international associations; 4) ensuring cooperation between higher education institutions and entrepreneurial structures in research and development [6]. It should be noted that in these countries, the level of allocation of budgetary funds for education $(7.8 \%$, with an average of $4.9 \%)$ is high (compared to other European countries).

We will analyze the peculiarities of the functioning of higher education system in Sweden, which is defined as unitary. In the process of reforms carried out from the 80's to the middle of the 90's, a united holistic system of higher education was created in this country. It is based on 15 universities (13 state and 2 private) and 25 university colleges. At the same time, older and more powerful are the universities in the city of Lund (founded in 1666, 42 thousand students, the largest in Northern Europe), in the city of Uppsala (founded in 1477, about 40 thousand students), as well as in Gothenburg, Stockholm. Relatively young are universities in Karlstad (1977), Luleå (1971), Orebro (1977). Two higher education establishments specializing in scientific research are Caroline Medical Institute (founded in 1819) and Royal Institute of Technology in the city of Stockholm (1827), tantamount to universities [9].

A fairly well-established and widespread form of education in Sweden are Summer School at universities. We should note that they function mainly on the territory of the University of Lund, Helsingborg, Umeå, Veksje, Malmö, Haparang and others. Their goal is to attract foreign students, teachers and researchers to study various problems of social development in Sweden, in the European community and in the whole world in a format of wide discussion [7].

Another sector of university education, which is relatively new, since it began to develop only in the 1990's, is presented by university specialized colleges. There are 25 of them in Sweden. They all have the right to issue general university diplomas, with the exception of doctoral ones.

It should be noted that about half of the students in the higher education system study humanities, one third of the students study engineering technologies and natural sciences. The teaching staff is about 30 thousand (on average, one teacher per 10 students). In general, about 50 thousand people work at higher education establishments in Sweden.

An essential feature of the educational process in higher education institutions in Sweden is the emphasis on the so-called responsible education, based on the slogan "Freedom and Responsibility!" 
This means that students have less study time than other countries and study mainly individually or in groups. The atmosphere in higher education institutions is characterized by a relaxed, informal relationship between students and teachers.

An example of a university that accumulates the best features of the functioning of higher education in Sweden is the University of Lund. As of 2012 - 2013 academic year, it (according to the results given in the doctoral thesis by T. Logvynenko) [7] included 47,000 students and 6,300 teachers from around the world. The structure of the university includes eight faculties, several research centers and specialized institutes. It implements cooperation with 680 partner universities from more than 50 countries of the world. Lund University has always implemented innovative approaches to organizing the educational process, providing international contacts, raising the level of education and quality of knowledge.

This is the only institution of higher education that is a member of two prestigious international networks: the "League of European Research Universities" and "University 21", in which it collaborates with leading universities - leaders of Europe and the world. As you know, "University-21" unites 20 leading research powerful universities from 12 countries. Within these networks, students' mobility is intensified when they have the opportunity to study abroad for a certain period; doctoral students - to spend some time in scientific training at a foreign educational institution; teachers - to work abroad.

Lund University focuses on the development of joint projects, such as joint educational programs, joint international summer schools. In this context, Lund University offers more than 300 English language courses for students from abroad who are studying in exchange programs.

It should be noted that in modern conditions, an important task of higher educational institutions is interaction with the society, which is realized in cooperation with industrial enterprises, as evidenced by the organization of "innovation parks" in southern Sweden, through which projects of subjects of various activities are carried out, students have different types of internships at profile enterprises [6].

A significant feature of the universities of Sweden is a significant opportunity for scientific research, that is, they are centers of science. The bulk of state-funded research work is carried out at universities. They have permanent funds for research. The country allocates more finance on education and science than on defense [8].

It should be noted that one of the components of the educational system of Sweden is "life-long education". Known are such vectors of educational policy in this area:

- formal education (child care, school education, higher education, adult education, adult education associations);

- labor market and workplace (vocational training in the labor market, training in the workplace);

- civil society (family, local societies, educational organizations, volunteer non-governmental organizations) [5].

\section{CONCLUSIONS}

In general, the Scandinavian adult education, while preserving its national specificity, in its development adheres to the European tendencies.

Consequently, the higher education system in Sweden has its own national peculiarities due to the mentality of the population of these countries, which sometimes "do not bind", on the one hand, with other systems of the European educational space and, on the other hand, with the implementation of certain provisions of the 1999 Bologna Convention, which have certain negative consequences in the European educational space and which are being tried to localize in the countries of Scandinavia.

1. Let us pay attention to the problem of financing higher education institutions, which is the subject of constant international discussions. It is essential that in Sweden, Denmark, Norway, the state priority is to provide free education based on the introduction of the so-called anti-market model, aimed at blocking market relations in the field of higher education. The position of its supporters is that, for the further development of the welfare of the society, the state must assume all responsibility 
for the financing of higher education, albeit at the cost of introducing new taxes (first of all, by increasing the taxation of large property). The idea of an anti-market model is to ensure equal conditions and opportunities for higher education for all citizens. In addition, student personality development should be the concern of the whole society and be free from the dominant influence of the market [8].

2. In our opinion, essential for understanding the specifics of the Scandinavian and, in particular, the Swedish system of education, is the point of view that it should develop only in the format of the state sector of the economy, outside the private sector. Otherwise, the logical result will be the inevitable transformation of higher education institutions into educational businesses, in which knowledge will be exchanged exclusively for money. Such logic of movement will lead to the total commercialization of the sphere of higher education, separation of unwealthy people from it and its subsequent polarization.

However, returning to the general European format of the Bologna Convention, it should be noted that functioning of the anti-market model, closed for any privatization of institutions of higher education, is possible only in developed countries, which are the Scandinavian countries, which choose the need for a conceptual definition of the development of the higher education sector only thanks to state institutions of higher education, thereby limiting the functioning of private institutions of higher education. Such countries fully provide funding for the higher education sector at the expense of the state. In addition, the population, in particular, supports this position by students (ibidem), sometimes, let us emphasize, by quite radical means.

So, in the autumn of 2013, the students from Swedish universities protested against plans of the Swedish government to privatize the country's universities and reduce the state subsidies for the faculties of the humanities and social sciences, as well as the introduction of paid studies at the universities of Stockholm, Lund, Goteborg and Uppsala. The students through social networks distributed the information with appeals to take part in the demonstrations. Some initiators suggested that the scale of protests could be compared to the student's revolution in 1968.

We would like to explain that the students' protest was caused by the government proposal, which was the attempt to make Sweden's universities more independent of the state by converting them from administrative departments to funds. It is known that today there are two higher education institutions in Sweden that are administered by private foundations, namely: the Higher Technical School - the Chalmers Foundation and the Higher School Foundation in Jonkoping. The change in the organizational structure was offered on a voluntary basis to ten largest higher education institutions in Sweden [10].

3. A significant aspect of the "mismatch" of higher education in Sweden with the Bologna Convention is the standardization of approaches, regulated by its format, to the organization of the educational process and the functioning of higher education in the European Union, which led, in the eyes of individual researchers, to the loss of distinctive national, mental, historical, cultural, demographic characteristics of each separate education system. That is, one of the most valuable features of Europe was lost - the balance of unity and otherness.

One cannot but agree with T. Zhyzhko's assertion that under the pressure of globalization, in fact, national education systems all over the world are put forward before their choices - whether to try to maintain their own traditions and standards, or to concede the expansion of more dynamic and competitive educational models, risking to lose a significant portion of their own identity. In general, globalization in education leads to its internationalization, standardization of knowledge and the formation of a unified system of values [2].

4. A critical analysis, for example, is required for such a phenomenon in modern higher education in Sweden as the phenomenon of competition among European countries for attracting the best students to study from different parts of the world, that is, the phenomenon of accelerated development of higher education transnationality in the format of the rapid growth of international academic mobility of students. A this it should be noted that in the ranking of more prestigious institutions of higher education in the world in recent years, there has been only one Swedish, namely, 
Caroline Medical Institute. Universities of Lund and Uppsala are no longer among the top 100 rated by the Times Higher Education. The first lines of the list are permanently occupied by such American universities as Harvard University, Massachusetts Institute of Technology and Stanford, followed by the British Cambridge and Oxford [10].

Therefore, these positions update the need for an adequate response to the current challenges and a thorough understanding of all possible risks to the Ukrainian economy. A significant problem in the context of modern processes of globalization of education is the sharp competition of higher education institutions, which leads to the outflow of the youth abroad. The result of this policy has become a significant increase in the number of Ukrainian students enrolled in education in Poland (more than 5 times in several years), which in total exceeds 10 thousand people and makes up more than one third of the entire foreign student contingent of Poland. Higher education institutions of Western Ukraine already experience the consequences of this phenomenon and, along with the general negative dynamics of demographic trends in our country, it poses serious risks for the national system of higher education [13].

Consequently, there is a clear negative assessment of the phenomenon of youth attraction to obtain higher education abroad, but there should be taken into account the right of young people to free choice in obtaining education. In addition, this mobility of the Ukrainian students will lead, if it is organized reasonably, to development, strengthening of cultural, scientific, and other ties between the countries and the saturation of the Ukrainian labor market with highly skilled professionals.

It is appropriate to recall the remarkable maxim: "Risk is an event that has not taken place yet but which activates the action" [1]. The dominant in this approach it is to the point to consider the "action" as a complex of measures for reorientation from the residual principle of financing higher education, reference to the lack of budget funds, the search for various opportunities for reducing costs, including the loss of intellectual potential to the priority financial support for higher educational institutions on the basis of the combination of budget and private sources of financing, industry and business, etc.

As the well-known diplomat, scientist and educator G. Khoruzhyi said justly, universities should have the right to develop their strategy, to choose certain priorities in studying and conducting scientific research, to spend their resources accordingly, to profile their programs and to set their criteria for the admission of professors and students. Nevertheless, while higher education institutions should be given autonomy in their internal affairs, such autonomy must be accompanied by clear and transparent accountability to governments, parliaments, students and society as a whole [11].

The same opinion is shared by other well-known analysts (M. Dmytrychenko, D. Kucherenko, T. Logvynenko, O. Martynyuk, L. Myrgorodska). The realities of Ukraine's economic development (first of all, the lack of budget funds) require the implementation of the principle of multi-channel financing of education with the involvement of extrabudgetary sources. These include not only the funds already received from individuals and legal entities at the expense of the contractual system of training, but also funds from sponsors and public and international organizations within the framework of assistance programs and the promotion of the education sector [4].

In this aspect, the experience of the developed countries of the world, including the Scandinavian countries, with the reform and systematic modernization of higher education is of considerable scientific interest to us. In Ukraine, as in Sweden, social infrastructures - institutions and agencies of culture, education, science, and public health - have been preserved. However, they are easy to lose, if their existence is not financed and supported. It should be remembered that the national intellectual aristocracy - the scientific and spiritual, and its successors - the youth, students - must be under the unceasing patronage of the state. Moreover, that education, science, culture are the most significant signs of the level of civilization of any state. 


\section{REFERENCES}

[1] Bek U. Risk Society. On the Way to another Modern. Progress-Tradition, Moscow, 2000. (in Russian)

[2] Zhyzhko T.A. The Philosophy of University Education of XXI century: Attempts of Prognostic Analysis. National Pedagogical Dragomanov University, Kyiv, 2010. (in Ukrainian)

[3] Ivanov A.N. Constants of the Swedish Culture in the Light of the The saurus Approach. Knowledge. Understanding. Skill, 3 (2009), 237-241. (in Russian)

[4] Kucherenko D.H., Martyniuk O.V. Strategies of Development of Educational Systems of Countries of the World. IPK DSZU, Kyiv, 2011. (in Ukrainian)

[5] Lohvynenko T.O. Lifelong learning: trends Swedish development. The Pedagogical Process: Theory and Practice, 3 (1) (2010), 255-263. (in Ukrainian)

[6] Lohvynenko T.O. Higher Education in Denmark, Norway, Sweden in the Modern European Space. Scientific Bulletin of Uzhhorod University. Series: "Pedagogy. Social work", 30 (2014), 86-89. (in Ukrainian)

[7] Lohvynenko T. Training of Social Workers at Universities in the Nordic countries: Denmark, Norway, Sweden. Vydavnychyi viddil DDPU, Drohobych, 2015. (in Ukrainian)

[8] Myrhorodska L.O. The Financial Systems of Foreign Countries. Tsentr uchbovoi literatury, Kyiv, 2008. (in Ukrainian)

[9] Antyushina N.M., Deryabin Yu.S. (Eds.) Northern Europe. The Region of New Development. Ves' Mir, Moscow, 2008. (in Russian)

[10] Filippovets L.F. Study Abroad. Nordic Countries. AST: Vostok - Zapad, Moscow, 2006. (in Russian)

[11] Horuzhyi H.F. European Higher Education Policy. Dyvosvit, Poltava, 2016. (in Ukrainian)

[12] HusénT. Education in 2000. Progress, Moscow, 1977. (in Russian)

[13] Available at: https://www.unian.net/world/846760-polsha-vpervyie-operedila-germaniyu-pokolichestvu-studentov-iz-ukrainyi.html

Address: Dmytro Zhelanov, G. S. Skovoroda Kharkiv National Pedagogical University, 29, Alchevskyh (Artema) Str., Kharkiv, 61000, Ukraine.

E-mail: zhdv91@gmail.com

Received: 24.12.2018; revised: 22.03.2019.

Желанов Дмитро. Вища освіта Швеції: європейські стандарти і скандинавський стидь. Журнал Прикарпатського університету імені Василя Стефаника, 6 (1) (2019), 126-132.

У статті розглянуто певні аспекти розвитку вищої освіти Швеції в контексті сучасних глобалізаційних, інтеграційних соціально-економічних процесів у країнах Євросоюзу. Проаналізовано позицію щодо особливостей сучасної вищої освіти, які пов'язані з ії виходом за межі окремих держав та трансформацію в міжнародну інституцію. Доведено, що ця обставина детермінуе значні досягнення в комплексному розвитку європейської вищої освіти, водночас, залишаючи ризики втрати їі національних особливостей і падіння рівня вищої освіти в країнах, недостатньо орієнтованих на добробут населення. Обгрунтовано необхідність урахування сутності цих ризиків задля підвищення конкурентоспроможності українських закладів вищої освіти у їх взаємозв'язку та співпраці 3 університетами Європи. Доведено доцільність вивчення й упровадження у вітчизняну систему вищої освіти кращого зарубіжного досвіду, зокрема країн Скандинавії, а саме Швеції.

Ключові слова: Болонська конвенція, глобалізація, европейській освітній простір, вища освіта Швеції, університети, коледжі, літні школи, країни “загального добробуту”, “освіта впродовж життя". 